\title{
Protein phase instability developed in plasma of sick patients: clinical observations and model experiments
}

\author{
Tatiana Yakhno
}

Department of Radio-Physical Methods in Medicine, Institute of Applied Physics RAS, Nizhny Novgorod, Russia; tanya-yakhno@rambler.ru

Received 6 November 2009; revised 1 January 2010; accepted 26 January 2010.

\begin{abstract}
This article discusses the causes of formation of micron-size protein structures in liquid plasma or serum of the patients with different diseases, which are accompanied by inflammatory reactions. Self-organizing processes in sessile drying drops of natural and model biological liquids are used for study of possible mechanisms of development the protein phase instability in serum. There was shown that violation of optimal ratio between albumin and osmotic active components could lead to loss of albumin aggregative stability and albumin coagulation structures formation. Possible role of these structures in pathogenesis of inflammation is discussed.
\end{abstract}

Keywords: Protein Aggregation in Serum; Mechanisms of Inflammation

\section{INTRODUCTION}

In 2003 we reported that micron-size protein structures were observed in liquid samples of serum and plasma of patients with different diseases in acute stage [1]. We could not give a correct explanation of this phenomenon at that time, but it seemed to be very interesting and important for blood physiology as one of possible nonspecific reactions of blood proteins accompanying inflammation. When these samples of plasma or serum were placed in the form of drops on glass for drying, the protein structures usually partly melted, and formed a structured film consisting of agglutinated particles. In serum and plasma of healthy people such structures appeared only at a certain stage of drying, forming a light-diffusing ring around the central part of the dried drops [2]. Thus, we suggested that appropriate conditions for protein structure formation in normal biological fluids were developed at a definite moment during drop drying. We believe that these conditions may be found in model experiments using protein-salt water solutions.

Recently, protein phase transitions are widely studied in the bulk of model solutions by means of static and dynamic light scattering, small-angle neutron and x-ray scattering [3-8]. Phase separation is achieved by adding precipitation agents: inorganic salts $[4,5,8]$, polyelectrolytes and organic solvents $[3,4,8]$, as well as by changing the concentration, temperature, and $\mathrm{pH}$ level $[4,5,7,9]$. Experimental studies show that protein precipitation by salts requires an electrolyte concentration in the range of 1-10 mole [9]. Protein aggregation in cells and biological fluids is also a subject for investigation from the point of view of crowding, because biochemical processes proceed in a medium with high concentration $(50-400 \mathrm{mg} / \mathrm{l})$ of macromolecules of different types [10-12]. This may lead to formation of nonfunctional protein aggregates, which upset balance between the active components, corrupting their functions [12] and may even be toxic [13].

The critical protein charge required to induce protein-polyelectrolyte complex formation between bovine serum albumin (BSA) and some synthetic polyelectrolytes was found to vary linearly as a function of square root of ionic strength [14]. Formation of intrapolymer complexes between human serum albumin (HSA) and polyethylene glycol (PEG) showed formation of a water-soluble complex the size of which varied depending on both, ionic strength and molecular weight of PEG but remained unaltered when the mixing ratio of PEG and HSA was varied [15]. Serum glycosaminoglycans, such as heparin, chondroitin and glucuronic acid, are native polyelectrolytes [16], so it is reasonable to expect their complex formation with HSA under certain conditions. It is well known that abnormal protein aggregation is responsible for a variety of serious diseases, including eye cataracts [17-19], sickle-cell anemia [20] and Alzheimer disease [21]. It was shown also that the dynamics of phase transitions in sessile drying drops of biological liquids can be used as a sensitive parameter for medical diagnostics [22-24].

The goal of this work is to attract the attention of medical blood researchers to the phenomenon of protein structure formation in native human biological fluids and 
to display factors that may be responsible for this phenomenon using the drop drying model. Here we show the data of model experiments with protein-salt water solutions, and compare them with the data of our clinical investigations carried out in 2000-2003.

\section{MATERIALS AND METHODS}

We used bovine serum albumin solutions (BSA, $68 \mathrm{kDa}$, Sigma, USA) in distilled water or in salt-water solutions with different protein/salt ratios. Salts $(\mathrm{NaCl}, \mathrm{KCl})$ were labeled "chemically pure" ("Reaktiv, Inc.", Russia). Experiments were also performed with lyophilized preparations of human serum proteins supplied by OOO IMTEK, Russia: 1) Human serum albumin (HSA, Sigma, USA, \#A-1653, $67 \mathrm{kDa}, \mathrm{pI} \approx 4.7, E(280 \mathrm{~nm}, 1 \%)=6.7) ; 2)$ immunoglobulin $\mathrm{G}(\mathrm{IgG}, 150 \mathrm{kDa}, E(280 \mathrm{~nm}, 1 \%)=14)$; $3)$ immunoglobulin $\mathrm{M}(\operatorname{IgM}, 900 \mathrm{kDa}, \mathrm{pI} \approx 7.2, E(280$ $\mathrm{nm}, 1 \%)=12)$; and 4) fibronectin (Fn, $420 \mathrm{kDa}, E(280$ $\mathrm{nm}, 1 \%)=13)$. Also $10 \% \mathrm{wt}$ food gelatin solution in distilled water or in physiological salt solution was used. To clarify a contribution of macromolecular serum components to albumin aggregation, model protein mix was prepared (Table 1). The mixed sample was compared with pure HSA-salt water solution of the same concentration. All solutions were prepared without buffering, a day prior to experimentation, refrigerated overnight and allowed to come to room temperature before testing. The samples under study were placed, using micropipette, onto clean glasses in the form of drops $3 \mu \mathrm{l}$ in volume (6-8 drops for each sample), and let for drying in room conditions. Morphological observations were carried out during drying, and 2-3 days after placing on the glasses, using МБС-10 and Люмам-И-3 microscopes with video camera computer setup.

Samples of blood plasma and serum were obtained from 30 clinically healthy donors (the material supplied by Hemotransfusion Station, Nizhny Novgorod); 18 patients with viral hepatitis $\mathrm{B}$ and $\mathrm{C}$ in acute stage (the material supplied by the Hepatological Center, Nizhny Novgorod); 30 patients with burn disease, and 8 patients with diseases of articulations of inflammatory and degenerative character (supplied by the Federal Burn Treatment Center, Nizhny Novgorod Research Institute of Traumatology and Orthopedics); 40 women after normal or premature (second- and third-trimester) childbirth (supplied by the maternity and child-welfare services of Nizhny Novgorod); one patient with Waldenstrom's macroglobulinemia, and seven patients with paraproteinemic hemoblastosis, with genetically modified IgG (supplied by the Research Institute of Epidemiology and Microbiology, Nizhny Novgorod). The samples were transported at $+4{ }^{\circ} \mathrm{C}$, heated up to room temperature, and then analyzed. The test fluids were applied on chemically clean glass slides either as small drops (six to seven 5-ul drops per slide) or as large drops $(0.5 \mathrm{ml}$ per slide). The slides were dried in room conditions ( $\mathrm{T}$ $=18-22^{\circ} \mathrm{C}, \mathrm{H}=60-70 \%$ ) for $24-48 \mathrm{~h}$. Thus, drying of the fluids occurred under different thermodynamic conditions depending on their volume and the shape of the drops. Some of the samples (small droplets) were dried under an МБС-10 microscope fitted with a television camera connected to a computer, so that phase transitions in the fluid could be recorded. After drying, the drops were studied in а Люмам-ИЗ or МБС-10 microscopes under conventional illumination conditions. Biochemical data of blood of the patients under investigation were obtained from the corresponding clinical laboratories, and statistical data were calculated using the Excel program.

\section{RESULTS}

The dried drops of protein solutions had a disc-like shape with a thick protein ring around the edge and a thinner circular central zone. Salt-free solutions formed homogenous transparent dried spots (Figure 1(a,b)), while protein-salt water dried drops had distinct concentric zones: external protein ring, ring of light-diffusing protein structures, ring of clear gel, and central zone of shrinking gel (Figure 1(c,d)) due to salt crystallization in it [2]. The above-named protein structures became visible mostly on the second day of drying, after partial evaporation of film water. So, when a drop is watched from the edge to the center in a transmitted light microscope, a homogenous layer of protein film is visualized first, then single micron-size protein aggregates are settled on the protein layer, after that fractal complexes are formed of these separated structures which finally turn into gel (Figure 1(e,f)). This principal sequence is the same for globular (BSA, HSA) and non-globular (gelatin) protein-salt water solutions regardless of protein and salt type and con centration. The difference is in morphological features and in the width of these zones, depending on the ionic strength/protein ratio. The protein ring in

Table 1. Content of model protein solutions in $0.9 \% \mathrm{NaCl}$ water solution.

\begin{tabular}{ccccccc}
\hline № & Sample content & Total protein, g/1 & HSA, g/l & Fn, g/l & IgG, g/l & IgM, g/l \\
\hline 1 & HSA + Fn + IgG + IgM & 84.5 & 70.0 & 0.3 & 12 & 2.2 \\
2 & HSA (control) & 84.5 & 84.5 & 0.0 & 0.0 & 0.0 \\
\hline
\end{tabular}


dried drops moves to the edge when the salt/protein ratio in the initial solution increases (Figure 2).

Earlier we found that IgG, IgM and Fn exert a considerable effect on both, the morphological and dynamic parameters of fluid structuring in drying drops through a change in the surface tension and viscoelastic properties of the adsorption layer at the fluid-air interface $[25,26]$. The goal of the current work is to elucidate how these macromolecular serum components influence protein structure formation during drop drying. We replaced part of HSA in physiological salt solution by different serum macromolecules with the same weight proportions (Table 1), and saw a different type of protein structures in dried drops in comparison with the control sample (Figure 3). They looked like large-scale agglutinated particles following the homogenous protein ring at the drop's edge. We chose the concentrations of the macromolecular
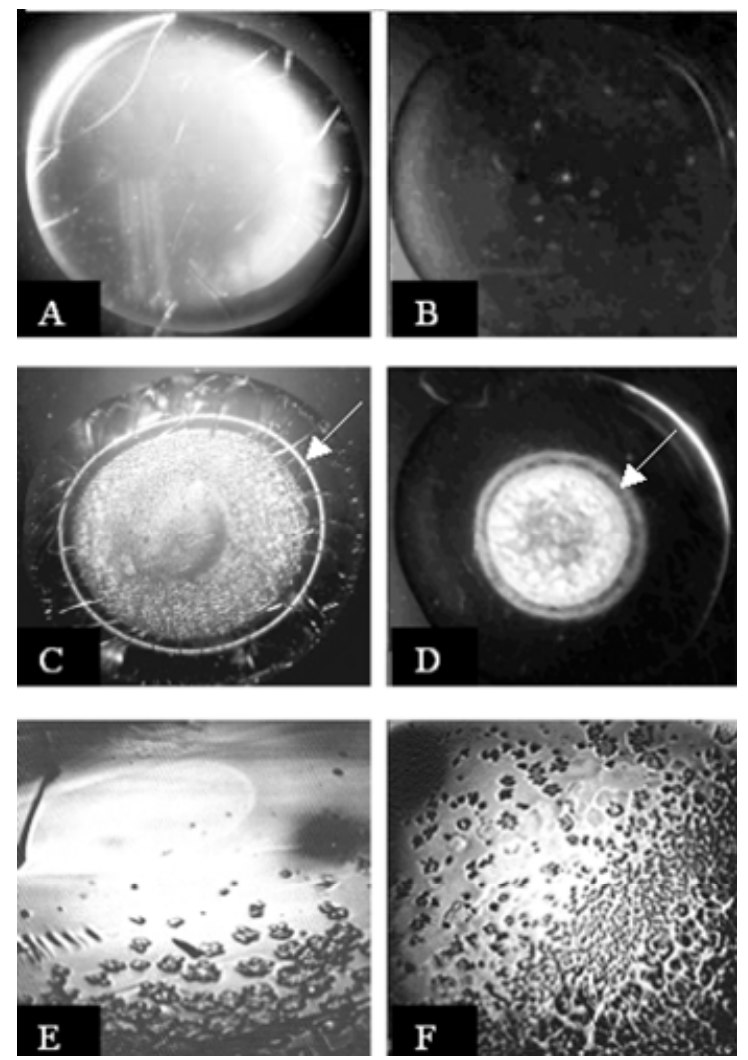

Figure 1. Dried drops of protein water solutions and their fragments. (a) - 7\% wt BSA in distilled water; (b) $-10 \%$ wt gelatin in distilled water; (c) - - 7\% wt BSA in $0.9 \% \mathrm{wt}$ $\mathrm{NaCl}$ solution; (d) - $10 \%$ wt gelatin in $0.9 \%$ wt $\mathrm{NaCl}$ solution; (e) - fragment of a peripheral zone of a dried drop C with protein structures on the homogenous protein layer; (f) - fragment of a peripheral zone of a dried drop d with protein structures on a homogenous protein layer. Arrows (c, d) show light-diffusion rings of protein structures. a-d shown at $\times 28$ original magnification using МБИ-3 microscope. (e) and (f) shown with original magnification $\mathrm{x}$ 140 (e) and 70 (f) using Люмам-ИЗ microscope and videocamera computer setup.
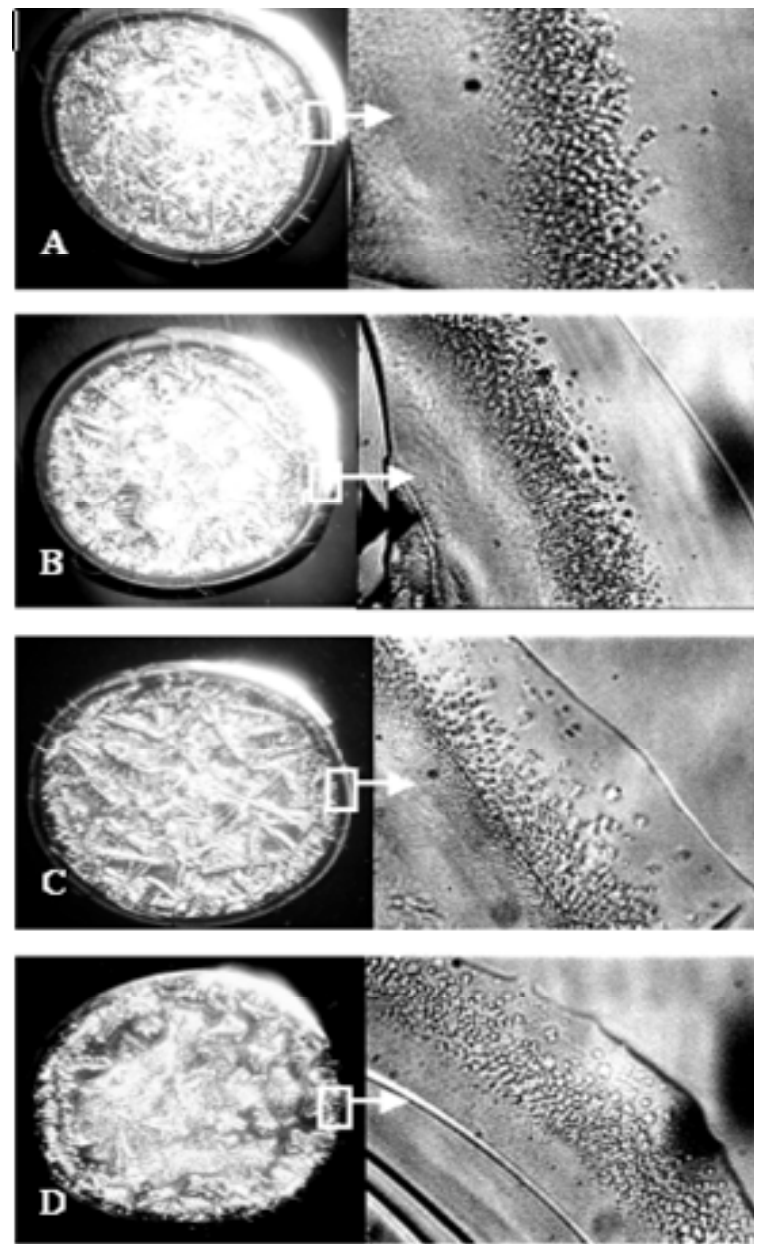

Figure 2. Dried drops of $\mathrm{NaCl} / \mathrm{BSA}$ water solutions with different $\mathrm{NaCl} / \mathrm{BSA}$ ratio (right), and their peripheral zones, are labeled with rectangle (left). $\mathrm{NaCl} / \mathrm{BSA}$ weight concentrations are the following: (a) $-1.3 / 6.0$; (b) $-1.5 / 5.0$; (c) $1.8 / 4.3$; (d) - 2.2/3.4. Increasing in salt/albumin ratio leads to moving protein structures zone to the drop's edge (left). (a-d) (left) shown at $\times 28$ original magnification using a microscope МБИ-3. (a-d) (right) shown at origin magnification $\times 70$ using a microscope Люмам-ИЗ and video-camera computer setup.

components approximately close to their normal concentration in blood [27].

These observations suggest that protein structures begin to form at a definite stage of drying of protein-salt water solutions, and this phenomenon is inherent in all the samples under study. Ionic strength, protein concentration and serum macromolecule components present in the initial solution influence structure formation. Surprisingly, sometimes we could see micron-size protein structures in liquid samples of plasma or serum of patients with different diseases (Figure 4(b-d)). They were never observed in liquid samples of healthy people (Figure 4(a)), but were usually formed at a definite stage of drop drying. Peripheral protein zones in dried drops of blood serum of healthy patients had the same order as 

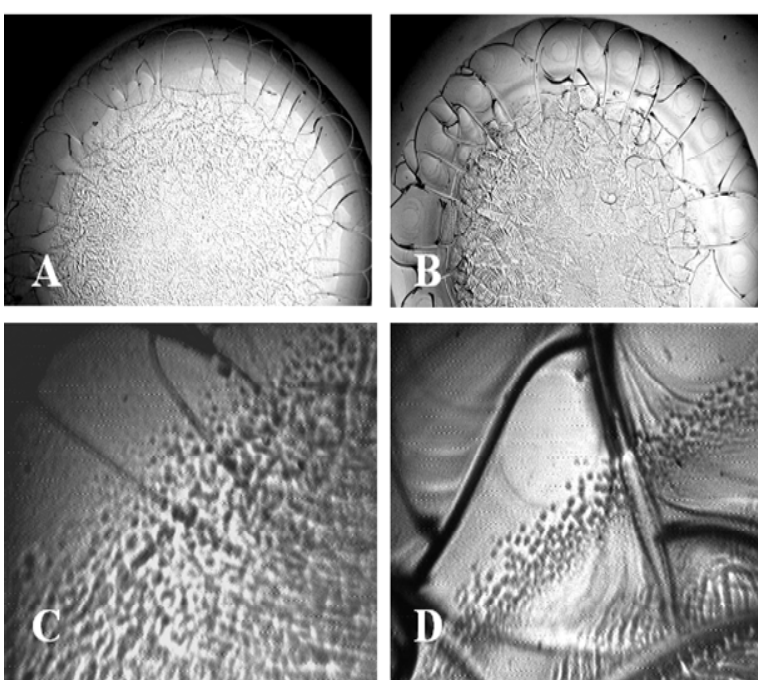

Figure 3. Influence of macromolecular serum components on protein structure formation in drying drops. (a) - a dried drop of mixed protein solution (HSA+Fn+IgG+IgM) in $0.9 \% \mathrm{wt} \mathrm{NaCl}$ water solution with total protein concentration $84.5 \% \mathrm{wt}$; (c) - fragment of peripheral zone of the drop a; (b) - a dried drop of $84.5 \%$ wt HSA solution in $0.9 \%$ wt $\mathrm{NaCl}$ water solution (control, see Table 1); (d) - fragment of peripheral zone of the drop b. In contrast to the control sample, zone of protein structures in c looks as large-scale agglutinated particles. $a$ and $b$ shown at $\times 28$ original magnification using МБИ-3 microscope. $\mathrm{c}$ and $\mathrm{d}$ shown at original magnification $\times 70$ using Люмам-ИЗ microscope and video-camera computer setup.
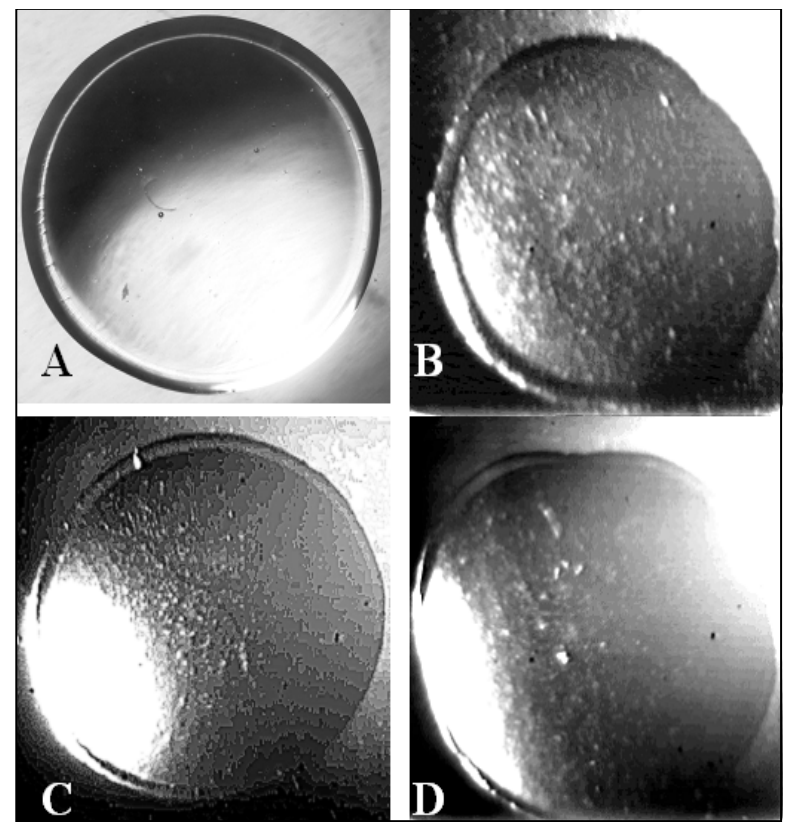

Figure 4. Fluid sessile drops of biological liquids at the very beginning stage of drying. (a) - serum of practically healthy donor; (b) - serum of patient with chronic hepatitis $b$ and chronic hepatitis c; (c) - plasma of patient with burn disease; (d) - serum of patient with coxarthrosis. Shown at original magnification using a microscope МБИ-3. Drop diameter is $5 \mathrm{~mm}$.
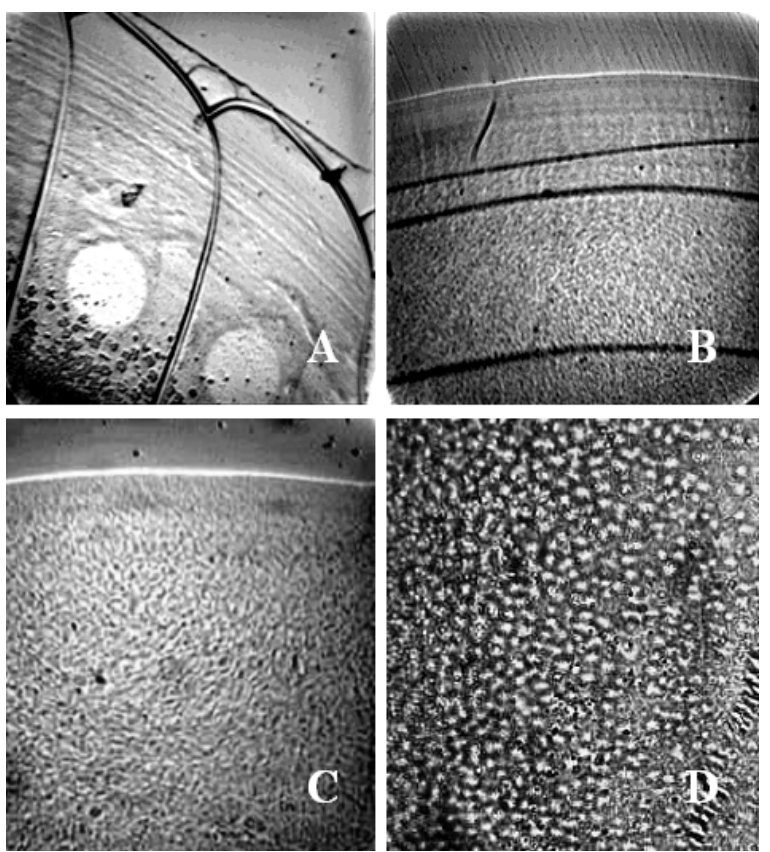

Figure 5. Peripheral zones of dried drops of serum. (a) practically healthy donor; (b) and (c) - two patients with burn disease; (d) - patient with paraproteinemia (overproduction of genetically modified IgG). The drop a has a homogenous protein film over the edge, then zone of protein structures begins. In the drops b-d zone of homogenous protein is absent. This zone is represented by agglutinated protein particles. Shown at original magnification $\times 70$ using Люмам-ИЗ microscope and video-camera computer setup.

model protein-salt water solutions: homogenous protein, ring of protein structures, and gel (Figure 5(a)). In the serum of patients with burn disease and paraproteinemia, the very first zone

was a structural protein film instead of a homogenous one (Figure 5(b-d)). This film consisted of a lot of small agglutinated protein structures. Microscopic investigation of big $(0.5 \mathrm{ml})$ drops showed that irrespective of the disease type, these protein structures didn't differ from each other in principle (Figure 6).

Albuminemia is a usual state of acute-phase reactions of different diseases [28]. Thus, average content of total protein and albumin was estimated by the example of burn disease patients and healthy donors. Also, plasma osmolarity was calculated using the empiric equation:

Osmolarity $(\operatorname{mosm})=195.1+0.74 \mathrm{Na}(\mathrm{mM} / \mathrm{l})+0.25$ $\mathrm{N}$ of blood urea $(\mathrm{mg} \%)+0.03$ Glucose $(\mathrm{mg} \%)$.

Figure 7(a-c) shows the results of the calculations. Thus, burn disease was characterized by total proteinemia due to albuminemia and a tendency to excess of plasma osmolarity. It is clear that the ratio of osmotic active components to albumin content in plasma increases in burn disease, and tends to norm during treatment (Figure 7(d)). At the same time, the peripheral zone of dried serum drops becomes more homogeneous. 

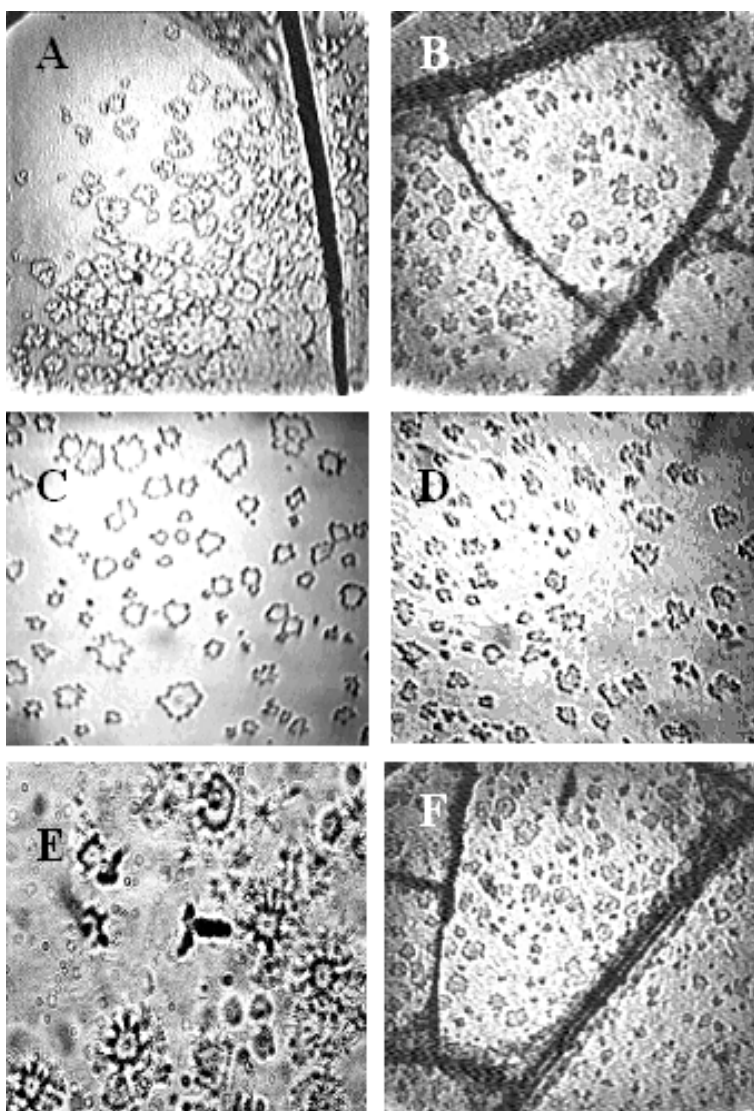

Figure 6. Protein structures in dried samples of serum of patients with different diseases. (a) and (b) - two patients with acute viral hepatitis $\mathrm{b}$; $\mathrm{c}$ and $\mathrm{d}$ - two patients with burn disease; (e) - a patient with Waldenstrom's macroglobulinemia; (f) - a woman after premature birth. Shown at original magnification $\times 70$ (a-d and f) and 140 (e) using Люмам-ИЗ microscope and video-camera computer setup.

\section{DISCUSSIONS}

Desiccated sessile drops of colloidal suspensions are good objects for studying liquid instabilities and nonequilibrium pattern formation [29]. The main principles of deposit ring formation over the circle ("coffee drop deposit"), as well as pattern formation, depending on particle size, concentration, ionic strength, and surfactant presence [30] were revealed in drying drops of model colloidal suspensions of polystyrene microspheres in water. Detailed description can also be found in [31,32]. The point is that a redistribution of protein content along drop radius occurs at the beginning of drop drying: up to $70 \%$ of albumin moves to the drop's edge and solidifies there, forming a ring, whereas the central part of the drop is still a liquid [2]. At the same time, salt concentration enhances in the liquid center due to water evaporation, and the salt/protein ratio increases. It can lead firstly to liquid-liquid protein separation in the form of coalescention, and subsequent solidification of neogenic micelles because of outside osmotic pressure increases.
AFM investigation of appropriate zone of a dried drop of a protein-salt water solution allowed finding a structure that seemed to be a precursor of a micron-size protein aggregates that were observed via optical microscope. It consisted of rounded substances-subunits with a radius about $50 \mathrm{~nm}$ [2]. Then, those quasi-solid albumin particles began to aggregate into micron-size structures forming fractal clusters, which finally transformed into gel. Thus, a gradual increase of the salt/albumin ratio was a driving force for this cascade of albumin structures formation in drying drops of albumin-salt water solutions. In a similar manner, increasing of osmolarity/albumin ratio in the samples of biological liquids was one of the main promoters of structure formation too. Increasing in concentration of macromolecules of different nature also promoted loss of colloid stability. The capacity of large unfolded protein molecules to bind and transform water to a structured state $[33,34]$ decreases the volume of free biologically active water, which plays an important role in prevention of coagulation. On the other hand, surfactants and polyelectrolytes under appropriate conditions can interplay with albumin, forming coacervates.

Cooper, C.L., et al. [35] (Figure 4) succeeded in viewing by eye in a tube coacervate/dilute equilibrium phase separation and polyelectrolyte-protein complexes formation (BSA, labeled with fluorescein isothiocynate, and poly (diallyldimethylammonium chloride).
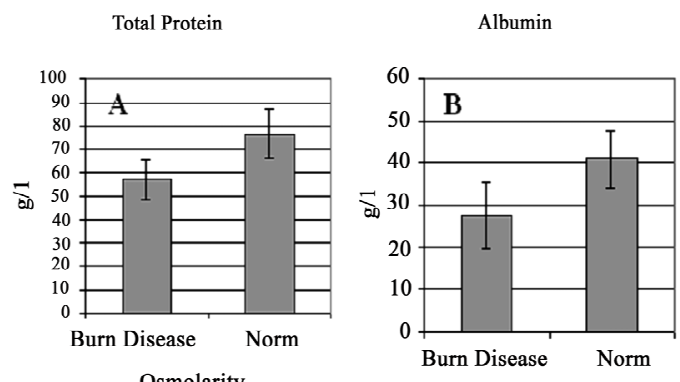

Osmolarity

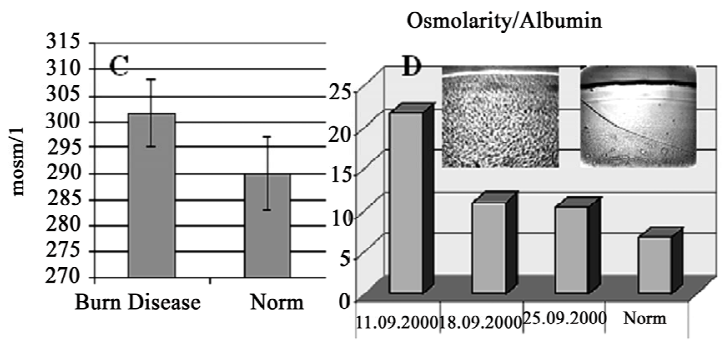

Figure 7. The data of serum protein content and osmolarity in norm compared with patients with burn disease. (a) - Total protein (g/l); (b) - Albumin (g/l); (c) - osmolarity (mosm/l); (d) - the dynamics of osmolarity/albumin ratio during treatment in a patient with burn disease. Microscopic images show the peripheral zones of dried drops at the beginning of treatment (left) and after two weeks of treatment (right). One can see the transformation of a structural protein film to a homogenous film. 
Coacervates were prepared at $\mathrm{pH} 9.5$ and $\mathrm{I}=0.1 \mathrm{M} \mathrm{NaCl}$. It is interesting to compare this data with our observations of the same phenomenon in serum of a patient with Waldenstrom's macroglobulinemia [1], when serum in a tube segregated spontaneously into two transparent liquid fractions differing in light-refracting capacity: lower density at the top and higher density at the bottom. Upon drying, the structures of interest were observed in the bottom fraction only, as well as in the thoroughly mixed whole serum. The transparency of these complexes meant that they were well hydrated, and "invisible". During film water evaporation they lost their water shell, and became visible. Appearance of such structures in liquid samples of biological fluids means that this complex system serum or plasma - transforms to a non-equilibrium state due to the presence of blood macromolecules, including acute-phase proteins, and osmotic active components which violate mutual balance and lead to loss of colloid stability.

Albumin is the most mysterious multifunctional blood protein. In norm, albumin realizes ligand-binding and transport functions, as well as supports colloid osmotic pressure of plasma and regulates neutrophyl function [36]. It has already been found that albumin specifically binds with low molecular weight molecules that might be important diagnostic and prognostic indicators of diseases [37]. In clinics, albumin has been intensively used in critical conditions, including vascular collaps in seriously ill patients [38]. At the same time, it was shown that highly purified commercial albumin preparations for laboratory use may contain significant amounts of albumin polymers [39-41]. There was an increase in death among patients who were treated with human albumin solution for burns, hypoalbuminaemia and hypotension [42] by up to $6 \%$. Pro and contra for using albumin in clinical practice are widely discussed in the literature [43].

It was shown that albumin polymers [44] and their glycation olygomers [45] promote erythrocyte rouleaux formation in blood, whereas molecular protein prevents erythrocyte aggregation [46]. Armstrong, J.K., et al. (2004) [47] have found that dimension of hydrodynamic radius of polymer or macromolecule is the main criterion of its erythrocyte aggregation capacity: if it does not exceed $4 \mathrm{~nm}$, it prevents aggregation, and if it is more than $4 \mathrm{~nm}$, it promotes it. Thus, in accordance with these data, molecular albumin is a promoter of erythrocyte disaggregation, and albumin polymers (or albumin coagulation structures) are promoters of their aggregation. Shacter, E., et al. (1993) [48]have reported that albumin polymers presented in commercial samples of albumin can stimulate interleukin- 6 and prostaglandin $\mathrm{E}_{2}$ production by macrophags in vitro and in vivo. The albumin fraction with molecular weight $\geq 600 \mathrm{kD}$ had the highest stimulation activity. It means that this polymer contains 10 or more monomers. The authors [48] believe that this is a new mechanism of cytokine activation that triggers a cascade of inflammatory reactions in organism.

This short review demonstrates that protein coagulation structures formed in biological fluids due to loss of their colloid stability can start the same cascade of pathophysiological reactions. In addition, protein coagulation leads to decreasing of blood oncotic pressure and to water penetration into intercellular space which encloses a vicious circle forming edema and worsening microcirculation. Thus, this phenomenon requires further investigation, strong laboratory control and elaboration of methods for its physical-chemical corrections if necessary. The drop drying process is a natural model of "functional loading" on biological liquids by decreasing albumin concentration and increasing ionic strength, which allows one to evaluate the degree of its colloid stability.

\section{REFERENCES}

[1] Yakhno, T.A., Sedova, O.A., Sanin, A.G. and Pelyushenko, A.S. (2003) On the existence of regular structures in the liquid human blood serum (plasma) and phase transitions in the course of its drying. Technical Physics, 48(4), 399-403.

[2] Yakhno, T. (2008) Salt-induced protein phase transitions in drying drops. Journal of Colloid and Interface Science, 318, 225-230.

[3] Velev, O.D., Kaler, E.W. and Lenhoff, A.M. (1998) Protein interactions in solution characterized by light and neutron scattering: comparison of lysozyme and chymotripsinogen. Biophysical Journal, 75, 2682-2697.

[4] Thomson, J.A., Schurtenberger, P., Thurston, G.M. and Benedek, G.B. (1987) Binary liquid phase separation and critical phenomena in protein/water solution, Proceedings of the National Academy of Sciences, USA, 84, 7079-7083.

[5] Kaibara, K., Okazaki, T., Bohidar, H.B. and Dubin, P.L. (2000) $\mathrm{pH}$-induced coacervation in complexes of bovine serum albumin and cationic polyelectrolytes, Biomacromolecules, 1,100-107.

[6] Seyrek, E., Dubin, P.L., Tribet, C. and Gamble, E.A. (2003) Ionic strength dependence of protein-polyelectrolyte interactions. Biomacromolecules, 4, 273-282.

[7] Wang, Y., Kimura, K., Huang, Q., Jaeger, W. and Dubin, P.L. (1999) Effects of salt on polyelectrolyte-micelle coacervation. Macromolecules, 32, 7128-7134.

[8] Tanaka, S., Yamamoto, M., Ito, K., Hayakawa, R., Ataka, M. (1997) Relation between the phase separation and the crystallization in protein solutions. Physical Review E, 56(1), R67-R69.

[9] Chang, B.H. and Bae, Y.C. (2003) Salting-out in the aqueous single-protein solution: the effect of shape factor. Biophysical Chemistry, 104, 523-533.

[10] Fulton, A.B. (1982) How crowded is the cytoplasm? Cell, 30(2), 345-347.

[11] Ellis, R.J. and Minton, A.P. (2006) Protein aggregation in crowded environments. Journal of Biological Chemistry, 387, 485-497. 
[12] Zimmerman, S.B. and Trach, S.O. (1991) Estimation of macromolecule concentrations and excluded volume effects for the cytoplasm of Escherichia Coli. Journal of Molecular Biology, 222, 599-620.

[13] Vazquez, A., Beg, Q.K., Demenezes, M.A. and Ernst, J., Bar-Joseph, Z., Barabasi, A.L., Boros, L.G., Oltavi, Z.N. (2008) Impact of the solvent capacity constraint on E. Coli metabolism. BMC Systems Biology, 2, 7-10.

[14] Mattison, K.W., Dubin, P.L. and Brittain, I.J. (1998) Complex formation between bovine serum albumin and strong polyelectrolytes: Effect of polymer charge density. Journal of Physical Chemistry B, 102, 3830-3836.

[15] Azegami, S, Tsuboi, A., Izumi, T., Hirata, M., Dubin, P. L., Wang, B. and Kokufuta, E. (1999) Fotmation of an intrapolymer complex from human serum albumin and poly(ethylene glycol). Langmuir, 15, 940-947.

[16] Tripp, B.C., Magda, J. J. and Andrade, J.D. (1995) Adsorption of globular proteins at the air/water interface, as measured via dynamic surface tension. Concentration dependence, mass-transfer considerations, and adsorption kinetics. Journal of Colloid and Interface Science, 173, 16-27.

[17] Pande A., Pande, J., Asherie, N., Lomakin, A., Ogun, O., King, J.A., Lubsen, N.H., Walton, D. and Benedek, G.B. (2000) Molecular basis of a progressive juvenile-onset hereditary cataract. Proceedings of the National Academy of Sciences, 97(5), 1993-1998.

[18] Simpanya, M.F., Ansari, R.R., Suh, K.I., Leverenz, V.R. and Giblin, G.J. (2005) Aggregation of lens crystallins in an in vivo hyperbaric oxygen Guinea pig model of nuclear cataract: dynamic light-scattering and HPLC analysis. Investigative Ophthalmology \& Visual Science, 46, 4642-4651.

[19] Stradner, A., Foffi, G., Dorsaz, N., Thurston, G. and Schurtenberger, P. (2007) New Insight into cataract formation: Enhanced stability through mutual attraction. Physical Review Letters, 99, 198103.

[20] Green, M.A., Noguchi, C.T., Keydan, A.J., Marwah, S.S. and Stuart, J. (1998) Polymerization of sickle cell hemoglobin at arterial oxygen saturation impairs erythrocyte deformability. Journal of Clinical Investigation, 81, 1669-1674.

[21] Ahn, S.-M., Byun, K., Cho, K., Kim, J. Y., Yoo, J. S., Kim, D., Paek, S. H., Kim, S. U., Simpson, R. J. and Lee, B. (2008) Human microglial cells synthesize albumin in brain. Plos ONE, 3(7), e2829.

[22] Yakhno, T.A., Yakhno, V.G., Sanin, A.G., Sanina, O.A. and Pelyushenko, A.S. (2003) A Method for Liquid Analysis by means of Phase Transitions during drop drying. Proceedings of SPIE, Bioengineered and Bioinspired Systems, 19-21 May, Maspolamas, Gran Canaria, Spain, 5119, 87-99.

[23] Yakhno, T., Sanin, A., Yakhno, V., Pelyushenko, A., Egorova, N.A., Terentiev, I.G., Smetanina, S.V., Korochkina, O.V. and Yashukova, E.V. (2005) The informative-capacity phenomenon of drying drops. Aptitude test in medical diagnostics. IEEE Engineering in Medicine and Biology Society, 24, 2, 96-104.

[24] Yakhno, T., Sanin, A., Pelyushenko, A., Kazakov, V., Shaposhnikova, O., Chernov, A., Yakhno, V., Vacca, C., Falcone, F. and Johnson, B. (2007) Uncoated quartz resonator as a universal biosensor. Biosensors and Bioelectronics, 22, 9-10, 2127-2131.

[25] Yakhno, T.A., Kazakov, V.V., Sanin, A.G., Shaposhnikova, O.B. and Chernov, A.S. (2007) Dynamics of Phase Transitions in Drying Drops of Human Serum Protein Solutions. Technical Physics, 52(4), 515-520.

[26] Yakhno, T.A., Kazakov, V.V., Sanin, A.G., Shaposhnikova, O.B. and Chernov, A.S. (2007) Mechanical Properties of Adsorption Layers in Solutions of Human Blood Serum Proteins: A Comparative Assessment. Technical Physics, 52(4), 510-514.

[27] Heil, W., Koberstein, R. and Zawta, B. (2001) Reference Ranges for Adults and Children: Pre-Analytical Considerations. Boehringer, Mannheim, 1997, Labpress, 176, Moscow.

[28] Ben-Ami, R., Barshtein, G, Mardi, T., Deutch, V., Elkayam, O. and Berliner, S. (2003) A synergistic effect of albumin and fibrinogen on immunoglobulin-induced red blood cell aggregation. American Journal of Physiology, Heart and Circulatory Physiology, 285, H2663-H2669.

[29] Shacter, E., Arzadon, G.K. and Williams, J.A. (1993) Stimulation of interleukin-6 and prostaglandin E2 secretion from peritoneal macrophages by polymers of albumin. Blood, 82, 2853-2864.

[30] Deegan, R.D. (2000) Pattern formation in drying drops. Physical Review E, 61(1), 475-485.

[31] Popov, Y. (2005) Evaporative deposition patterns: Spatial dimensions of the deposit. Physical Review Letters, 71, 036313.

[32] Yakhno, T. and Yakhno, V. (2009) Structural evolution of drying drops of biological fluids. Technical Physics, 54(8), 1219-1227.

[33] Ling, G.N. (2000) Life at the cell and bellow-cell level. The hidden history of a fundamental revolution in biology. Pacific Press, 280. Also available: http://biopa radigma.narod.ru/hidden history/ling newbook.htm

[34] Pollak, G.H. (2001) Cells, gels and the engines of life. Ebner \& Sons, Seattle, 301. WA, USA.

[35] Cooper, C.L., Dubin, P.L., Kayitmazer, A.B., Turksen, S. (2005) Polyelectrolyte-protein complexes. Current Opinion in Colloid and Interface Science, 10, 52-78.

[36] Peters, T. (1996) All about albumin: Biochemistry, genetics, and medical applications. San Diego, Academic press.

[37] Petricoin, E.F., Belluco, C., Araujo, R.P., Liotta, L.A. (2006) The blood peptidome: A higher dimension of information content for cancer biomarker discovery. Nature Reviews Cancer, 6, 961-967.

[38] Quinlan, G.J., Martin, G.S., Evans, T.W. 2005. Albumin: Biochemical properties and potential. Hepathology, 41, 1211-1219.

[39] Keyser, J.W. (1995) Standardization of dye-binding methods for estimation of serum albumin. Clinica Chimica Acta, 11, 477-9.

[40] Blaaberg, O. and Hylton, P.P. (1979) Effect of aggregates on albumin standardization. Scandinavian Journal of Clinical and Laboratory Investigation, 39, 751-7.

[41] Bormer, O.P., Amlie, L.M., Paus, E. and Kongsgard, U. (1999) Automated albumin method underestimates pharmaceutical-grade albumin in vivo. Clinical Chemistry, 45(7), 1082-1084. 
[42] Reviewers, C.I.G.A. (1998) Human albumin administration in critically ill patients: Systematic review of randomised controlled trials. British Medical Journal, 317, 235-240.

[43] Pulimood, T.B. and Park, G.R. (2000) Debate: Albumin administration should be avoided in the critically ill. Critical Care, 4, 151-155. Also available: http://ccforum/ content $/ 4 / 3 / 151$

[44] Forsdyke, D.R., Palfree, R.G.E. and Takeda, A. (1982) Formation of erythrocyte rouleaux in preheated normal serum: roles of albumin polymers and lysophosphatidylcholine. Canadian Journal of Biochemistry, 60(7), 705-711.

[45] Candilores, H., Muller, S., Ziegler, O., Donner, M. and Drouin, P. (1996) Role of albumin glycation on the erythrocyte aggregation: An in vitro study. Diabetic Medicine, 13(7), 646-650.

[46] Reinke, W., Gaehtgens, P. and Johnson, P.C. (1987) Blood viscosity in small tubes: effect of shear rate, aggregation, and sedimentation. American Journal of Physiology, 253(3), H540-547.

[47] Armstrong, J.K., Wenby, R.B., Meiselman, H.J. and Fisher, T.C. (2004) The hydrodynamic radii of macromolecules and their effect on red blood cell aggregation. Biophysical Journal, 87, 4259-4270.

[48] Deegan, R.D., Bakajin, O., Dupont, T.F., Huber, G., Nagel, S.R., Witten, T.A. (2000) Contact line deposits in an evaporating drop. Physical Review E, 62(1), 756-776. 